\title{
Effect of Dividends on Stock Prices- A Case of Chemical and Pharmaceutical Industry of Pakistan
}

\author{
Kanwal Iqbal Khan \\ Faculty of Commerce, University of Central Punjab, Pakistan
}

\begin{abstract}
Corporate sector of Pakistan is adversely facing competition due to economic downturn in the world and making efforts to survive in a competitive and uncertain economic environ ment. Th is study will help to ameliorate dividend decisions of corporate sector through felicitously appropriate implementation of their dividend policies. This paper is an attempt to explicate the affect of dividend announcements on stock prices of chemical and pharmaceutical industry of Pakistan. A sample of twenty nine companies listed at KSE-100 Index is taken from the period of 2001 to 2010. Results of this study is predicated on Fixed and Random Effect Model which is applied on Panel data to explicate the relationship between dividends and stock prices after controlling the variables like Earnings per Share, Profit after Tax and Return on Equity. The Results show that Stock Dividend, Earnings per Share and Profit after Tax have a significant positive relation to stock market prices and significantly explicates the variations in the stock prices of chemical and pharmaceutical sector of Pakistan while Retention Ratio and Return on Equity have the negative insignificant relation with stock prices. This paper further shows that Dividend Irrelevance Theory is not applicable in case of chemical and pharmaceutical industry of Pakistan.
\end{abstract}

Keywords Cash Dividend, Stock Dividend, Stock Price, Fixed and Random Effect Model, Dividend Irrelevance Theory

\section{Introduction}

Dividend policy is one of the most widely researched topics in the field of finance but the question whether dividend policy affects stock prices still remains debatable among managers, policy makers and researchers for many years. Dividend policy is important for investors, managers, lenders and for other stakeholders. It is important for investors because investors consider dividends not only the source of income but also a way to assess company from investment point of view. It is the way of assessing whether the company is cash generative or not. Selecting a suitable dividend policy is an important decision for the company because flexibility to invest in future projects depends on the amount of dividends that they pay to their shareholders. If a company pays more dividends than fewer funds available for investment in future projects. Lenders are also interested in the amount of dividend that a company declares, as more amounts is paid as dividend means less amount would be available to the company for servicing and redemption of their claims and finally it is important for other stakeholders especially for claim holders to help them in reducing agency cost.

* Corresponding author:

Kanwaliqbal99@yahoo.com (Kanwal Iqbal Khan)

Published online at http://journal.sapub.org/mm

Copyright (C) 2012 Scientific \& Academic Publishing. All Rights Reserved
The basic objective of shareholder is to maximize their return and this return may be in the form of dividends or capital gain. Investors' decisions regarding the return on investment are affected by the dividend policy of the company. Arnold (2008) explains the main objective of dividend policy is to maximize shareholders' wealth by maximizing their purchasing power. So maximizing shareholders' wealth depends on the dividend policy of the company because of these shareholders would satisfy their purchasing and consumption patterns.

There are certain important factors that companies consider in designing their dividend policies like the managerial and behavioural environ ment, firms' profitability ratios, the willingness of the company etc. Ju ma'h \& Pacheco (2008) believe that management decision of dividend policy is affected by the managerial and behavioural environ ment in the U.S. They further explain that sometimes financially strong companies do not pay dividend and financially weak companies pay dividends. According to their opinion dividend paying companies are generally larger in size, profitability, in terms of liquidity ratio and in research and developments as compared to non-dividend paying companies. Ling, Mutalip, Shahrin, \& Othman (2008) studied the characteristics of dividend paying companies of Malaysia. The results of their study show that dividend paying companies are more profitable, less risky and more mature in their activities as compared to non-dividend paying companies. Their results also indicate that managers 
of Malaysian companies understand the importance of paying dividends and they pay dividends even if the companies are not earning profits.

The objective of this research is to see the effect of cash dividend and stock dividend on stock prices of chemical and pharmaceutical industry of Pakistan. For this purpose different articles written in Pakistan and abroad are reviewed and dividend theories have been empirically tested and their effect on stock prices has been observed. There are mainly two schools of thoughts available in the field of finance that presented two different opinions about the dividend policy. One school of thought followed the opinion of Miller and Modigliani (1961) and considered dividend policy irrelevant while the second school of thought followed the point of view of Gordon (1963) and considered dividend policy relevant. Since the half century passed, the question still remains i.e. whether dividend policy is relevant or not. This dilemma yet exists, which theory the companies should apply for making their dividend decisions.

The significance of this study is that it has used Retention Ratio as a determinant of dividend policy which is previously ignored by Pakistani researchers like Nishat \& Irfan (2003), Nazir, Nawaz, Anwar, \& Ahmed (2010), Asghar, Shah, Hamid \& Suleman (2011), Nazir, Abdullah \& Nawaz (2012) and Habib, Kiani \& Khan (2012) etc. These Pakistani researchers used either Dividend Yield or Payout Ratio or both of them as a determinant of dividend policy. This article also explicates the effect of Stock Dividend along with Cash Dividend on Stock Prices after controlling the variables like Return on Equity, Earnings per Share and Profit after Tax.

\section{Literature Review}

Many studies have been conducted on dividend policies earlier which explicate the relationship between dividend policy and stock prices. These studies help new researchers explore the dividend policy in a new way. Discussion of dividend policy cannot be completed without including the work of Linter (1956). Linter (1956) raised the question, which is still important, "what choices made by managers do affect the size, shape and timing of dividend payments?" After the contribution of Linter (1956), Miller \& Modigliani (1961) introduced the concept of Dividend Irrelevance theory in which they explain that dividend policy does not affect the stock prices. Many researchers like Black \& Scholes (1974), Chen, Firth, \& Gao (2002), Adefila, Oladipo \& Adeoti (2004), Uddin \& Chowdhury (2005), Denis \& Osobov (2008) and Adesola \& Okwong (2009) provide strong evidence in the favour of the dividend irrelevance theory and does not consider it relevant to the stock prices.

Gordon (1963) gave another view about the dividend policy by presenting the concept of dividend relevance theory. They said that dividend policy does affect the value of the firm and the market price of shares. Investors always prefer secure and current income as dividends over capital gains. Studies conducted by Travlos, Trigeorgis, \& Vafeas (2001), Baker, Powell \& Veit (2002), Myers \& Frank (2004), Dong, Robinson \& Veld (2005) and Maditinos, Sevic, Theriou, \& Tsinani (2007) support dividend relevance theory. Black \& Scholes (1974) found no relationship between dividend policy and stock prices. Their results further explain that dividend policy does not affect the stock prices and it depends on investors' decision to keep either high or low yielding securities; return earned by them in both cases remains the same.

Barclay and Smith (1995) in their article "The Maturity Structure of Corporate Debt" found that high growth companies have lower Dividend Payouts and Debt Ratios than the low growth companies, which have higher Dividend Payouts and Debt Ratios. So investors prefer higher Dividend Payouts and consider it less risky than capital gain. Allen \& Rachim (1996) found no relationship between the dividend yield and stock market price even after studying 173 Australian listed stocks but it shows the positive relation between stock prices and size, earnings and leverage and negative relation stock prices and payout ratio while Baskin (1989) examines 2344 U.S common stocks from the period of 1967 to 1986, and found a significant negative relationship between dividend yield and stock price.

Another study conducted by Ho (2002) relevant to the dividend policy in which he uses the panel data approach and fixed effects regression model. The results of his study show the positive relation between dividend policy and size of Australian firm and liquidity of Japanese firms. He found the negative relation between dividend policy and risk in case of only Japanese firms. The overall industrial effect of Australia and Japan are found to be significant. Baker, Powell \& Veit (2002) in their article "Reinvesting Managerial Perspectives on Dividend Policy" provided new evidence of managers' decision about dividend policy. They conducted a survey of managers of NASDAQ firms that are consistently paying cash dividends. Their survey result shows that managers are mostly a ware of historical patterns of dividends and earnings. So, they design their dividend policies after considering it.

Pradhan (2003) also explained the effect of dividend payment and retained earnings on stock market price of the Nepalese companies. The results of his study show that dividend payment has strong relation with stock price while retained earnings have very weak relation with stock market price. His results further expla in that Nepalese stockholders give more importance to dividend income than capital gains. Nishat \& Irfan (2003) studied 160 companies listed at Karachi Stock Exchange for the period of 1981-2000. Their results were based on cross sectional regression analysis show that dividend yield and payout ratio is positively related to the share price volatility. Adefila, Oladipo \& Adeoti (2004) studied the factors affecting the dividend policy of Nigerian firms. The results of their study show that Nigerian firms prefer regular dividend payouts that can be in accordance with the expectations of their shareholders. Their results also conclude that there is no relation between 
Dividend Payments, Net Earnings and Stock Prices. Nigerian firms pay dividends to their shareholders regardless of their level of profits for satisfaction of their shareholders.

Myers \& Frank (2004) found positive relation between Price Earnings Ratio and Dividend Payout Ratio in their study by using the data of 483 firms from Multex Investor Database. Their results further show that there is a significant positive relation between Debt to Equity Ratio and Dividend Payout. Baker, Mukherjee, \& Paskelian (2006) explained the behaviour of Norwegian managers who used the survey technique in designing the dividend policy. The results of their survey show that current and future earnings, stability of earnings, the current degree of financial leverage, and liquid ity are the main determinant that corporate managers consider in designing their dividend policies. Their results provided the mixed opinion about the question: "whether dividend policy affects the firms' value or not”?

The results of the study conducted by Amidu (2007) studied the effect of dividend policy on the performance of the companies listed on the Ghana Stock exchange. The results of his study showed that there is a positive relation between Return on Assets, Dividend Policy and Growth in Sales and there is a negative relation between Return on Ass ets, Dividend Payout Ratio and Leverage. His results also support the results of previous studies that provide the strongest evidence for the relevance of dividend policy to the firms' performance. Pani (2008) took the sample of 500 companies from the six sectors of Bombay Stock Exchange in order to study the relationship between dividend policy and stock market prices. The results of his study show that the dividend retention ratio is positively related to stock returns in case of individual sector but there is no statistically significant relation between these variables. These results further show that debt equity ratio has the negative relation with stock return while the size of the firm has positive relationship with stock return. Another study conducted by Raballe \& Hedensted (2008) in Denmark during 1988-2004 identified the positive relationship between cash dividends and net earnings of the company, return on equity, retained earnings, size and last year profit but fail to find out any relation between the debt equity ratio and dividend decision in Denmark.

Denis \& Osobov (2008) empirically tested the trends of companies for designing their dividend policy. The results of their study show that the general trend in the US, Canada, UK, Germany, France, and Japan is that the companies having a higher profitability ratio and a higher fraction of retained earnings to total equity pay dividends to their investors. On the other hand, the companies that have lower profitability ratio and a lower fraction of retained earnings to total equity do not either pay dividend or pay at a low rate but still this all depends on the managerial and behavioral environment of the countries to decide whether they want to pay dividends or not

Ahmed \& Javaid (2009) conducted a study to analyse the determinants of dividend policy in the emerg ing economy of Pakistan by taking the sample of 320 companies listed on
Karachi Stock Exchange for the period of 2001 to 2006. The results of their study show that most of the Pakistani companies decide their dividend payment on the basis of profits i.e. current year or previous year profits. So the companies having high net profits pay a larger amount of dividends to their shareholders. Furthermore, their results showed that market liquidity is positively related to the dividend payout ratio and negative relationship was found between the firm size and payouts while there is no relationship between growth opportunities and dividend payment. The results of the study conducted by Adesola \& Okwong (2009) in which they empirically tested the factors affecting the dividend decisions of Nigerian companies show that dividend policy is significantly associated with earnings, earnings per share and previous year dividends but firms' growth and size have no effect on dividend policy.

Akbar \& Baig (2010) took the sample of 79 companies listed on Karachi Stock Exchange for the period of 2004 to2007 to study the effect of dividend announcement on stock prices. The results of their study show that announcement of dividends either Cash Dividend or Stock Dividend or both have a positive effect on Stock Prices. Nazir, Nawaz, Anwar, \& Ahmed (2010) also study the effect of dividend policy on stock prices. The results of their study show that dividend payout and dividend yield have a significant effect on stock prices while the size and leverage have a negative insignificant affect and earning and growth have a positive significant effect on stock prices.

Khan, Aamir, Qayyum, Nasir, \& Khan (2011) studied the effect of dividend payment on stock prices by taking the sample of fifty five companies listed at Karachi Stock Exchange. The results their study show that dividend yield, earnings per share, return on equity and profit after tax are positively related to stock prices while Retention Ratio has the negative relation to Stock Prices. As ghar, Shah, Hamid \& Suleman (2011) also explore the relationship between dividend policy and Price Volatility and found a positive relation between Price Volatility and Dividend Yield while Growth of Assets has a negative relation with Price Volatility. After including other explanatory variables, the relationship between Dividend Payout and Dividend Yield with Price Volatility become positive and it becomes negative with Earnings Volatility.

Hussainey, Mgbame, \& Chijoke-Mgbame (2011) studied the impact of Dividend Policy on Stock Prices. The results of their study show the positive relation between Dividend Yield and Stock Price Changes and negative relation between Dividend Payout Ratio and Stock Price Changes. Their results further indicate that the Firms' Earnings, Growth Rate, Level of Debt and Size also cause the change in the Stock Price of UK. Baker \& Powell (2012) has used survey techniques to take the opinion of Indonesian managers about the factors influencing dividend policy, dividend issues, and explanations for paying dividends. The results of their survey show that Indonesian managers consider stability of earnings and level of current and expected future earnings are the most important determinants 
of dividend policy. Their results further indicate that dividend policy affects firm value and Indonesian managers consider different dividend theories like signalling, catering, and life cycle theories in designing their dividend policies.

Habib, Kiani \& Khan (2012) used cross sectional regression analysis to find out the effect of dividend yield and payout ratio on stock prices. The results of their study show that dividend yield has a positive effect on stock prices while the payout ratio, size and debt negative effect on stock prices. This study suggests that dividend yield is better and more important determinant factor in determining share price volatility in KSE 100 index rather than payout ratio. Another study conducted by Nazir, Abdullah \& Nawaz (2012) to find out the effect of dividend policy on price volatility of financial firms of Pakistan. The results of their study show negative relation between dividend yield and dividend payout with price volatility. They also consider dividend policy as an important indicator for determining the stock prices in Pakistan.

Friend \& Puckett (1964), John \& Williams (1985), Asquith \& Mullins (1986), Richardson, Sefcik, \& Thompson (1986), Ambarish, Williams, \& John (1987) and Liaonly (2009) also found the positive association between dividends and stock market prices while Baskin (1989) found an inverse relationship between dividends and stock market prices whereas Black \& Scholes (1974) and Rachim (1996) failed to find out any type of relationship Allen \&between the dividend and stock price.

\section{Data Collection and Variable Definition}

Sample of twenty nine dividend paying companies are taken from the chemical and pharmaceutical industry of Pakistan for the period of ten years from 2001 to 2010 and dividend paying companies for this research are those that made at least four dividend payment in one of the ten years under study (2001-2010). The data has been collected from the audited annual reports of the companies listed on Karachi Stock Exchange for the period of 2001 to 2010. The purpose of this article is to see the relation between Dividend Policy and Stock Prices after controlling Earnings per Share, Profit after Tax and Return on Equity.

Price Volatility is taken as dependent variable which is calculated by using Parkinson (1980) method of extreme values. It is calculated by dividing the annual range of prices with the average of high and low stock prices. Then variance for the year 2001-2010 is averaged and is transformed into standard deviation. This method is considered better than the traditional methods in which researchers use either opening price or closing price or average of opening and closing prices. Parkinson (1980), Allen \& Rachim (1996), Nishat \& Irfan (2003), Pani (2008), Rashid \& Rahman (2009), Nazir, Nawaz, Anwar, \& Ahmed (2010), Khan and Aamir, Qayyum, Nasir, \& Khan (2011), Habib, Kiani \& Khan (2012) also used price volatility as a dependent variable in their studies.

Stock Dividend is an important type of dividends. Its effect on Stock Prices will depend on the perception of investors. So it can positively or negatively affect the Stock Prices. Horne, Wachowic z \& Kuhlemeyer (2004) expla in the effect of Stock Dividend by saying that it results in increasing the number of shares but decreases the price of share and Earnings per Share while the value of the firm does not change. Akbar \& Baig (2010), Khan, Aamir, Qayyum, Nasir, \& Khan (2011) and Travlos, Trigeorgis, \& Vafeas (2001) found a positive relation between stock dividends and stock prices.

Retention Ratio is calculated by subtracting Total Dividend from Total Earnings and then divided the resulting amount by Earnings. The negative or positive relation between Retention Ratio and Stock market Prices will depend on perception of investors. If investors think that company has more profitable opportunities than outside then it will positively affect the Stock market Prices otherwise it will negatively affect the Stock market Prices. Pani (2008) found a positive relation between dividend to Retention Ratio and Stock Prices while Khan, Aamir, Qayyum, Nasir, \& Khan (2011) found negative relation between dividends and stock prices.

Profit after Tax is also used as an important explanatory variable in this study and it is that it is positively related to Stock Prices. This relation is further confirmed by Pani (2008), Adesola \& Okwong (2009), Ahmed \& Javid (2009) and Khan, Aamir, Qayyum, Nasir, \& Khan (2011).

Earnings per Share is calculated by subtracting preferred stock from net income and by dividing the resulting amount with the number of outstanding shares. It is considered as an indicator for measuring the profitability of the companies. Howton \& Peterson (1999) have also analy zed the "effects of Betas, Size, Book-to-Market Equity, and Price Earnings Ratios on Stock Returns”. Baskin (1989), Allen \& Rachim (1996), Liu \& Hu (2005), Adefila, Oladipo \& Adeoti (2004), Adesola \& Okwong (2009) and Chen, Huang, \& Cheng (2009), Khan, Aamir, Qayyum, Nasir, \& Khan (2011) also used Earnings per Share as a control variable in their study and report the positive relation between Earnings per Share and Stock Prices while Adefila, Oladipo \& Adeoti (2004) does not find any relation between Stock Prices and Earnings.

Return on Equity is also considered as important variables in this study. Return on Equity is calculated by dividing profit after tax with shareholders' equity. It is expected that Return on Equity is positively associated with Stock market Prices. Liu \& Hu (2005), Raballe \& Hedensted (2008), Ling, Mutalip, Shahrin, \& Othman (2008) and Khan, Aamir, Qayyum, Nasir, \& Khan (2011) found a positive relation between Return on Equity and Stock Prices.

\section{Research Methodology}

This paper has used the panel data approach to measure 
the relation between Dividend Policy and Stock Prices. Fixed and Random Effect Models are applied on this panel data. Fixed Effect method is used to control all the stable characteristics of the companies included in the study over a fixed period of time. This method provides statistically better results by removing the biases from the data and explains only within the sample variations. Random Effect method is applied when characteristics of sample differs. As the characteristics of companies are different in terms of size, amount of capital, no. of shareholders, nature of business, earnings etc. so this method is suitable to explain variations between the companies. These methods are also adopted by Ho (2002), Pani (2008), Rashid \& Rahman (2009), Nazir, Nawaz, Anwar, \& Ahmed (2010), Hussainey, Mgbame, \& Chijoke-Mgbame (2011) and Khan, Aamir, Qayyum, Nasir, \& Khan (2011) in their studies.

The objective of this study is to see the effect of Dividend Policy and Stock Prices after controlling the variables like Earnings per Share, Profit after Tax and Return on Equity. It is expected that Stock Dividend, Earnings per Share, Return on Equity and Profit after Tax will be positively associated to Stock Market Prices i.e. increases in Stock Dividend, Earnings per Share, Return on Equity and Profit after Tax will result in increasing the stock prices of chemical and pharmaceutical industry of Pakistan while Retention Ratio is expected to have a negative relation with stock prices.

Following regression line is used in this study:

$$
\mathrm{PV}=\alpha_{0}+\alpha_{1} \mathrm{SD}_{\mathrm{i}}-\alpha_{2} \mathrm{RR}_{\mathrm{i}}+\alpha_{3} \mathrm{PAT}_{\mathrm{i}}+\alpha_{4} \mathrm{ROE}_{\mathrm{i}}+\alpha_{5} \mathrm{EPS}_{\mathrm{i}}
$$

\section{Results and Discussions}

Table 1 shows the descriptive statistics including mean, standard deviations, minimum and maximum value of all variables.

Table 1. Descriptive Statistics

\begin{tabular}{|c|c|c|c|c|c|}
\hline Variable & $\mathrm{N}$ & Minimum & Maximum & Mean & Std. Dev. \\
\hline PV & 290 & .00 & .39 & .0285 & .05742 \\
\hline SD & 290 & .00 & 40.00 & 3.3138 & 7.63550 \\
\hline RR & 290 & -265.67 & 2.13 & -6.3388 & 27.48737 \\
\hline PAT & 290 & -6234.00 & 4527.77 & 159.1811 & 894.40304 \\
\hline EPS & 290 & -61.09 & 228.17 & 9.2662 & 27.27590 \\
\hline ROE & 290 & -19.20 & 7.51 & .0851 & 1.25796 \\
\hline
\end{tabular}

The mean value of Pro fit after Tax variable is the highest i.e. 159.18 while mean value of Price Volatility is .0285 . The lowest mean value is -6.34 , which is the mean value of Retention Ratio. Standard Deviation shows the variation in the data. The highest value Standard Deviation is 894.4 which show that the great variation in the Market Prices of chemical and pharmaceutical sector of Pakistan is due to Profit after Tax. Return on Equity has a minimum value of Standard Deviation i.e. 1.258 which shows that Return on Equity causes minimum variation in the Stock Market prices of Chemical and pharmaceutical sector of Pakistan.

Table 2 shows the correlation among the different explanatory variables and with dependent variable i.e. Stock Market Prices. For this purpose Pearson Correlation method is used and the significance of these variables is tested at $1 \%$, $5 \%$ and $10 \%$ level of significance.

Table 2. Correlations

\begin{tabular}{|c|c|c|c|c|c|c|}
\hline $\begin{array}{c}\text { Variab } \\
\text { le }\end{array}$ & PV & SD & RR & PAT & EPS & ROE \\
\hline PV & 1.00 & & & & & \\
\hline & & & & & & \\
\hline SD & $.091^{* *}$ & 1.00 & & & & \\
\hline & .023 & & & & & \\
\hline RR & .042 & .037 & 1.00 & & & \\
\hline & .471 & .528 & & & & \\
\hline PAT & $.100^{*}$ & $.150^{* *}$ & -.007 & 1.00 & & \\
\hline & .090 & .011 & .912 & & & \\
\hline EPS & $.842^{* * *}$ & .073 & .048 & $.163^{* * *}$ & 1.00 & \\
\hline & .000 & .218 & .412 & .006 & & \\
\hline ROE & $.061^{*}$ & .061 & -.026 & $.369^{* * *}$ & $.108^{*}$ & 1.00 \\
\hline & .051 & .297 & .658 & .000 & .065 & \\
\hline
\end{tabular}

$* * *$ Correlation is significant at the 0.01 level (2-tailed)

** Correlation is significant at the 0.05 level (2-tailed)

*Correlation is significant at the 0.10 level (2-tailed)

Stock Market Prices of chemical and pharmaceutical sector of Pakistan have a significant relation with Stock Dividend, Profit after Tax, Return on Equity and Earnings per Share while Retention Ratio has insignificant relation to Stock Market Prices. This relations hip is significant at 1\%, $5 \%$ or $10 \%$ level of significance. Stock Dividend has insignificant relation with Earnings per Share, Retention Ratio and Return on Equity and significant relation with Profit after Tax at $5 \%$ or $10 \%$ levelof significance. Retention Ratio has insignificant relation to Earnings per Share, Return on Equity and Profit after Tax. Profit after Tax has a significant relation with Earnings per Share and Return on Equity at $1 \%, 5 \%$ and $10 \%$ level of significance. Earnings per Share has a significant relation with Return on Equity at $10 \%$ level of significance.

Table 3 shows the results of Fixed Effect Model and Table 4 shows the results of the Random Effect Model that further validates the results of Table 2 . These results explain the significance of individual determinant of dividend policy in the model and overall significance of the model.

Results of Fixed and Random Effect Models show that Stock Dividend, Profit after Tax and Earnings per Share has positive significant relation to Stock Market Prices while Retention Ratio has negative an insignificant relation to Stock Market Prices in case of both models. Return on Equity also has an insignificant relation with Stock Prices but this relation is negative in the case of Fixed Effect Model and positive in case of Random Effect Model. These results confirm that shareholders prefer dividends i.e. Stock or Cash Dividends. If companies pay Cash Dividend, it will positively affect its Stock Market Prices and if the company is unable to pay cash dividend then they prefer Stock Dividend because stock dividend increases their number of share and next time they will be able to receive more dividend on these shares. 
These results are consistent with the results of the study conducted by Akbar \& Baig (2010), Khan, Aamir, Qayyum, Nasir, \& Khan (2011) and Travlos, Trigeorgis, \& Vafeas (2001). Retention Ratio has negative and statistically insignificant relation to Stock Market Prices show the preference of shareholders for cash dividend. It also shows that shareholders found more profitable investment opportunities outside the firm. These results are consistent with the results of the study conducted by Khan, Aamir, Qayyum, Nasir, \& Khan (2011).

Table 3. Fixed Effect Model

\begin{tabular}{|c|c|c|c|c|}
\hline Variable & Coefficient & Std. Error & t-Statistic & Prob. \\
\hline $\mathrm{C}$ & 2.772250 & 0.526854 & 5.261894 & 0.0000 \\
\hline SD & 0.001425 & 0.000579 & 2.458831 & 0.0146 \\
\hline RR & -0.031183 & 0.032566 & -0.957541 & 0.3392 \\
\hline PAT & 0.008857 & 0.017888 & 0.495133 & 0.0209 \\
\hline $\mathrm{ROE}$ & -0.002335 & 0.407798 & -0.005725 & 0.9954 \\
\hline EPS & 0.218687 & 0.001526 & 15.18835 & 0.0301 \\
\hline & \multicolumn{3}{|c|}{ Effects Specification } & \\
\hline R-squared & 0.565844 & \multicolumn{2}{|c|}{ Adjusted R-squared } & 0.497293 \\
\hline F-statistic & 8.254352 & \multicolumn{2}{|c|}{ Prob. (F-statistic) } & 0.000000 \\
\hline
\end{tabular}

$\mathrm{PV}=2.77+0.0014 \mathrm{SD}-0.034 \mathrm{RR}+0.0089 \mathrm{PAT}-0.0023 \mathrm{ROE}+0.219 \mathrm{EPS}$

Table 4. Random Effect Model

\begin{tabular}{|c|c|c|c|c|}
\hline Variable & Coefficient & Std. Error & t-Statistic & Prob. \\
\hline C & 2.862603 & 0.517778 & 5.528634 & 0.0000 \\
\hline SD & 0.001227 & 0.000542 & 2.263260 & 0.0244 \\
\hline RR & -0.015527 & 0.030686 & -0.505992 & 0.6133 \\
\hline PAT & 0.009971 & 0.016259 & 0.613241 & 0.5402 \\
\hline ROE & 0.048137 & 0.382581 & 0.125822 & 0.9000 \\
\hline EPS & 0.161178 & 0.004349 & 11.16535 & 0.0265 \\
\hline \multicolumn{5}{|c|}{ Effects Specification } \\
\hline R-squared & 0.601816 & Adjusted R-squared & 0.513331 \\
\hline F-statistic & 6.801307 & Prob. (F-statistic) & 0.000000 \\
\hline
\end{tabular}

$\mathrm{PV}=2.86+0.0012 \mathrm{SD}-0.016 \mathrm{RR}+0.00997 \mathrm{PAT}+0.048 \mathrm{ROE}+0.161 \mathrm{EPS}$

Earnings per Share and Profit after Tax have positive and statistically significant relation to Stock Prices. This shows that these variables significantly explains the variations in Stock Market Prices because shareholders are only concerned with the amount of profits which is paid to them as dividends whether that amount is paid out of current profit or from previous year profit. The significant relationship between Profit after Tax, Earnings per Share and Stock Market Prices shows that if the companies increase their Earnings per Share Ratio and amount of profit, Market Prices increase and has a significant effect on Market Prices of shares, Ohlson (1995) also consider Earnings per Share as an important variable for financial statement by explaining that "stock value is a function of two financial statement variables (book value and earnings)”. These results are similar to the results of the studies conducted by Pradhan (2003) that show dividend payment has positive strong relation with Market Prices of share while retained earnings has the very weak relation to the stock market prices. Another study conducted by Dong, Robins on \& Veld (2004) also shows the positive relation between the Cash Dividend and Stock Market Prices. In case of Profit after Tax Pani (2008), Adesola \& Okwong (2009), Ahmed \& Javid (2009) and Al-Kuwari (2010) found a positive relation between stock prices and profit after tax.

Although Return on Equity has an insignificant relation with the Stock Market Prices but still it is important to be considered. Return on Equity has a negative effect on Stock Market Prices in the case of Fixed Effect Model. This negative relation shows the beliefs of shareholders that the company is not efficiently using their funds. Return on Equity has a positive effect on Stock Market Prices in the case of the Random Effect Model. This shows that management is efficiently using the shareholders' funds. Liu \& Hu (2005), Raballe \& Hedensted (2008) and Ling, Mutalip, Shahrin, \& Othman (2008) also found a positive relation between Return on Equity and Stock Prices. Khan, Aamir, Qayyum, Nasir, \& Khan (2011) also found negative relation in the case of Fixed Effect Model and positive in case of the Random Effect Model. The significant F value shows that the overall models are the good fit and all the variables included in these models are significantly explaining the variation in the stock prices.

\section{Conclusions}

This study is conducted to answer the questions that do dividend policy of chemical and pharmaceutical industry of Pakistan affect the stock prices? And what are the preferences of investors for dividends either cash or stock? For this purpose, sample of twenty nine companies listed at KSE-100 Index are taken from the period of 2001 to 2010. Panel data approach is used to analyse the relationship between Dividend Policy and Stock market Prices after controlling the variables like Profit after Tax, Earnings per Share and Return on Equity. The empirical estimation based on the Fixed and Random Effect Model shows the significant positive relation between Stock Dividend, Earnings per Share and Profit after Tax to Stock Market Prices while Return on Equity and Retention Ratio have negative and statistically insignificant relationship to Stock Market Prices.

These results show the preference of Pakistani investors for cash dividend and if the company is unable to pay cash dividend then they prefer stock dividend. Thus the dividend policy of chemical and pharmaceutical industry of Pakistan is an indicator of consistent performance of chemical and pharmaceutical industry and investors of these industries still prefer dividends either cash or stock in spite of tax advantage on capital gain.

The significant $\mathrm{F}$ value in the Fixed and Random Effect Model suggests that all the explanatory variables included in the model are considerably explaining the variations in the stock prices and dividend policy has significant positive effect on stock prices. These results further show that Dividend Irrelevance theories are not applicable in case chemical and pharmaceutical companies of Pakistan. The findings of this study show positive significant effect of dividend policy on stock prices and also the positive attitude of investors towards dividends either cash or stock. Although dividend policy play effective role in explaining the price 
volatility in emerging economy like Pakistan but still these results cannot be generalized to other developing countries because corporate structure of firms is different in these countries.

This research also has a constraint of including only dividend paying companies from Chemical and Pharmaceutical Industry of Pakistan listed at KSE-100 Index for the period of 2001 to 2010 and Dividend paying companies for this research are those that made at least four dividend payment in one of the ten years under study (2001-2010). Therefore, it is suggested that this study will help the future researchers to explore other sectors of Pakistan with small and large firm size and with the comparison of dividend paying and dividend non- paying companies. It also help them to conduct more researches on various determinants of dividend policy that may forecast the potential of financial markets, economic situations and price volatility in the emerging economies like Pakistan.

\section{REFERENCES}

[1] H. Kent Baker, Gary E. Powell, "Dividend Policy in Indonesia: Survey Evidence from Executives", Emerald Group Publishing Limited, Journal of Asia Business Studies, vol. 6, no. 1, pp. 79-92, 2012.

[2] Mian Sajid Nazir, Abdullah, Muhammad Musarrat Nawaz, "How Dividend Policy Affects Volatility of Stock Prices of Financial Sector Firms of Pakistan”, EuroJournals Publishing, Inc., American Journal of Scientific Research, no. 61, pp.132-139, 2012.

[3] Yasir Habib, Zernigah Irshad Kiani, Muhammad Arif Khan, "Dividend Policy and Share Price Volatility: Evidence from Pakistan”, Global Journals Inc. (USA), Global Journal of Management and Business Research, vol. 12, no. 5, pp. 78-84, 2012.

[4] Kanwal Iqbal Khan, Muhammad Aamir , Arslan Qayyum , Adeel Nasir , Mary am Iqbal Khan, "Can Dividend Decisions Affect the Stock Prices: A Case of Dividend Paying Companies of KSE”, EuroJournals Publishing, Inc., International Research Journal of Finance and Economics, no.76, pp. 67-74, 2011.

[5] Khaled Hussainey, Chijoke Oscar Mgbame, Aruoriwo M Chijoke-Mgbame, "Dividend Policy and Share Price Volatility: UK Evidence”, Emerald Group Publishing Limited, Journal of Risk Finance, vol. 12, no.1, pp. 57-68, 2011.

[6] Muhammad Asghar, Syed Zulfiqar Ali Shah, Kashif Hamid, Muhammad Tahir Suleman, "Impact of Dividend Policy on Stock Price Risk: Empirical Evidence from Equity Market of Pakistan”, Far East Research Centre, Far East Journal of Psychology and Business, vol. 4, no. 1, pp. 45-52, 2011.

[7] Mian Sajid Nazir, Muhammad Musarat Nawaz, Waseem Anwar, Farhan Ahmed, "Determinants of Stock Price Volatility in Karachi Stock Exchange: The Mediating Role of Corporate Dividend Policy”, EuroJournals Publishing, Inc., International Research Journal of Fin ance and Economics, no. 55, pp. 100-107, 2010.
[8] Muhammad Akbar, Humayun Habib Baig, "Reaction of Stock Prices to Dividend Announcements and Market Efficiency in Pakistan”, Published by Lahore School of Economics, The Lahore Journal of Economics, vol. 15, no. 1, pp. 103-125, 2010.

[9] Afzalur Rashid, A. Z. M. Anisur Rahman, "Dividend Policy and Stock Price Volatility: Evidence from Bangladesh", North American Business Press, Journal of Applied Business and Economics, vol. 8, no. 4, pp. 71-81, 2009.

[10] Dar-Hsin Chen, Hsiang-Hsi Liu, Cheng-Ting Huang, “The Announcement Effect of Cash Dividend Changes on Share Prices: An Empirical Analysis of China”, M.E. Sharpe, Inc., The Chinese Economy, vol. 42, no. 1, pp. 62-85, 2009.

[11] Hafeez Ahmed, Attiya Y. Javid, “Dynamics and Determinants of Dividend Policy in Pakistan (Evidence from Karachi Stock Exchange Non Financial Firms)”, Euro Journals Publishing, Inc., International Journal of Finance and Economics, no. 25, pp. 148-171, 2009.

[12] Online Available: http://liaonly.wordpress.com/, April, 2009.

[13] W. A. Adesola, A. E. Okwong, “An Empirical Study of Dividend Policy of Quoted Companies in Nigeria”, Bachudo Science Co. Ltd., Global Journal of Social Sciences, vol.8, no. 1, pp. 85-101, 2009.

[14] Ahmad H. Juma'h, Carlos J. Olivares Pacheco, “The Financial Factors Influencing Cash Dividend Policy: A Sample of U.S. Manufacturing Companies”, Revista Empresarial Inter Metro, Inter Metro Business Journal, vol. 4, no. 2, pp. 23-43, 2008.

[15] David J. Denis, Igor Osobov, “Why Do Firms Pay Dividends? International Evidence on the Determinants of Dividend Policy", Published by Elsevier, Journal of Financial Economics, vol. 89, no. 1, pp. 62-82, 2008.

[16] Few Say Ling, Mohd Lukman Abdull Mutalip, Aidil Rizal Shahrin, Mohd Said Othman, "Dividend Policy: Evidence from Public Listed Companies in Malaysia”, World Business Institute, International Review of Business Research Papers, vol. 4, No.4, pp. 208-222, 2008.

[17] Glen Arnold, Corporate Financial Management, 4th ed., Financial Times Pitman Publishing, London, 2008.

[18] Online Available: http://papers.ssrn.com, April 12, 2008.

[19] Online Available: http://ssrn.com/abstract=1216171, August 11, 2008.

[20] Dimitrios I. Maditinos, Zeljko Sevic, Nikolaos G. Theriou, Alexandra V. Tsinani, “Individual Investors' Perceptions Towards Dividends: The Case of Greece”, Inder Science Publishers, International Journal of Monetary Economics and Finance, vol. 1, no. 1, pp. 18-31, 2007.

[21] Mohammed Amidu, "How Does Dividend Policy Affect Performance of the Firm on Ghana Stock Exchange?", Business Perspectives Publishing Company, Investment Management and Financial Innovations, vol. 4, no. 2, pp. 103-112, 2007.

[22] H. Kent Baker, Tarun Mukherjee, Ohannes Paskelian, "How Norwegian Managers View Dividend Policy”, Published by Elsevier, Global Finance Journal, vol. 17, no. 1, pp. 155-176, 2006.

[23] Md. Hamid Uddin, Golam Mohammed Chowdhury, Effects 
of Dividend Announcement on Shareholders' Value: Evidence from Dhaka Stock Exchange”, Published by Elsevier, Journal of Business Research, vol. 7, pp. 61-72, 2005.

[24] Ming Dong, Chris A. Robinson, Chris Veld, “Why Individual Investors Want Dividends”, Published by Elsevier, Journal of Corporate Finance, vol. 1, no. 12, pp. 121-158, 2005.

[25] Shulian Liu, Yanhong Hu, "Empirical Analysis of Cash Dividend Payment in Chinese Listed Companies”, Marsland Press, Nature and Science, vol. 3, no. 1, pp. 65-70, 2005.

[26] James C. Van Horne, John M Wachowicz, Gregory A Kuhlemeyer, Fundamentals of Financial Management, 12th ed., Pearson Education Limited, England, 2004.

[27] J. J. Adefila, J. A. Oladipo, J. O. Adeoti, "The Effect of Dividend Policy on the Market Price of Shares in Nigeria: Case Study of Fifteen Quoted Companies”, University of Ado-Ekiti, International Journal of Accounting, vol.2, no.1, pp.1-10, 2004.

[28] Melissa Myers, Bacon Frank, "The Determinants of Corporate Dividend Policy”, The DreamCatchers Group, Academy of Accounting and Financial Studies Journal, vol. 8, no. 3, pp. 17-28, 2004.

[29] Mohammed Nishat and Chaudhary Mohammad Irfan, "Dividend Policy and Stock Price Volatility in Pakistan". in Proceedings of 2003 11th Pacific Basin Finance, Economics and Accounting Conference, 2003.

[30] Radhe Shyam Pradhan, "Effects of Dividends on Common Stock Prices: The Nepalese Evidence", Buddha Academic Publishers \& Distributors Pvt. Ltd., Research in Nepalese Finance, pp. 1-13, 2003.

[31] Gong-meng Chen, Michael Firth, Ning Daniel Gao, “The Information Content of Concurrently Announced Earnings, Cash Dividends, and Stock Dividends: An Investigation of the Chinese Stock Market”, John Wiley \& Sons, Ltd., Journal of International Financial Management and Accounting, vol. 13, no. 2, pp. 101-124, 2002.

[32] H. Kent Baker, Gary E. Powell, and E. Theodore Vei , "Revisiting Managerial Perspectives on Dividend Policy", Published by Springer, Journal of Economics and Finance, vol. 26, no. 3, pp. 267-283, 2002.

[33] Horace Ho, "Dividend policies in Australia and Japan", Published by Springer, International Advances in Economics Research, vol. 2, no. 9, pp. 91-100, 2002.

[34] Nickolaos Travlos, Lenos Trigeorgis, Nikos Vafeas, "Shareholder Wealth Effects of Dividend Policy Changes in an Emerging Stock Market: The Case of Cyprus", Multinational Finance Society, Multinational Finance Journal, vol. 5, no. 2, pp. 87-112, 2001.

[35] Shelly W. Howton, David R. Peterson, "A Cross Sectional Empirical Test of a Dual- State Multi- factor Pricing Model”, John Wiley \& Sons, Ltd., The Financial Review, vol. 34, no. 3, pp. 47-64, 1999.

[36] Dave E. Allen, Veronica S. Rachim, “Dividend Policy and Stock Price Volatility: Australian Evidence”, Taylor \&
Francis Group, Applied Financial Economics, vol. 6, no. 2, pp. 175-188, 1996.

[37] James A. Ohlson, "Earnings, Book Value and Dividends in Equity Valuation”, John Wiley \& Sons, Ltd., Contemporary Accounting Research, vol. 11, no. 2, pp. 661-687, 1995.

[38] Michael J. Barclay, Clifford W. Smith, "The Maturity Structure of Corporate Debt”, Blackwell Publishing for the American Finance Association, The journal of Finance, vol. 1, no. 2, pp. 609-631, 1995.

[39] Jonathan Baskin, "Dividend Policy and the Volatility of Common Stock", Institutional Investor, Inc. , Journal of Portfolio Management, vol. 3, no. 15, pp. 19-25, 1989.

[40] Ramasastry Ambarish, Joseph Williams, Kose John, "Efficient Signaling With Dividends and Investments", Blackwell Publishing for the American Finance Association, The Journal of Finance, vol. 42, no. 2, pp. 321-343, 1987.

[41] Gordon Richardson, Stephan E. Sefcik, Rex Thompson, “A Test of Dividend Irrelevance Using Volume Reactions to a Change in Dividend Policy”, Published by Elsevier, Journal of Financial Economics, vol. 17, no. 2, pp. 313-334, 1986.

[42] Paul Asquith, David W. Mullins, "The Impact of Initiating Dividend Payments on Shareholders' Wealth”, The University of Chicago Press, The Journal of Business, vol. 1, no. 46, pp. 77-96, 1986.

[43] Kose John, Joseph Williams, "Dividends, Dilution and Taxes: A Signaling Equilibrium”, Blackwell Publishing for the American Finance Association, The Journal of Finance, vol. 40, no. 4, pp. 1053-1070, 1985.

[44] Michael Parkinson, "The Extreme Value Method for Estimating the Variance of the Rate of Return”, Blackwell Publishing for the American Finance Association, The Journal of Business, vol. 53, no. 1, pp. 61-65, 1980.

[45] Fischer Black, Myron Scholes, "The Effects of Dividend Yield and Dividend Policy on Common Stock Prices and Returns”, Published by Elsevier, Journal of Financial Economics, vol. 1, no. 1, pp. 1-22, 1974.

[46] I. Friend, M. Puckett, "Dividends and Stock Prices", Blackwell Publishing for the American Finance Association, American Economic Review, vol. 54, no. 5, pp. 656-682, 1964.

[47] M. J. Gorden, “Optimal Investment and Financing Policy”, Blackwell Publishing for the American Finance Association, The Journal of Finance, vol. 18, no. 2, pp. 264-272, 1963.

[48] Merton H. Miller, Franco Modigliani, "Dividend Policy, Growth and Valuation of shares", Blackwell Publishing for the American Finance Association, The Journal of Business, vol. 34, no. 4, pp. 411-433, 1961.

[49] John Lintner, "Distribution of Incomes of Corporations among Dividends, Retained Earnings, and Taxes”, Blackwell Publishing for the American Finance Association, American Economic Review, vol. 46, no. 2, pp. 97-113, 1956. 